\title{
Finite Element Method usage in determining pressure distribution of periodontal tissues on maxillary canine as result of orthodontic force
}

\author{
Elih*), Tono S. Hambali*, Jono Salim*, Endah Mardiati* \\ *Department of Orthodontics Faculty of Dentistry Universitas Padjadjaran, Bandung
}

\begin{abstract}
The purpose of this study is to obtain data of pressure distribution on canine periodontal tissues due to orthodontic force generated by various types of motion using the Finite Element Method. The development of digital technology creates numerical analysis for orthodontic treatment that can be done by performing 3-D reconstruction by scanning the maxillary canine teeth with a CT scan, so that 255 cross-sectional images is obtained. $3 \mathrm{D}$ model is then processed using the Finite Element Method to obtain the pressure distribution on the periodontal tissues caused by tipping movements, bodily, torque, roots, rotation, and extrusion. Analysis used was the analysis of qualitative and quantitative analysis. The results showed that the maximum pressure that occurs in the periodontal tissues caused by a variety of movements ranging from $3.3 \times 10^{-3} \mathrm{MPa}$ to $2.9 \times 10^{-2} \mathrm{MPa}$. This indicates that the force exerted on each movement produces maximum pressure that exceeds capillary pressure was $2 \times 10^{-3} \mathrm{MPa}$.
\end{abstract}

Key words: Pressure distribution on the periodontal tissues, type of orthodontic movement, 3-D object reconstruction, Finite Element Method

\section{ABSTRAK}

Tujuan penelitian ini untuk memperoleh data mengenai distribusi tekanan pada jaringan periodontal gigi kaninus yang dihasilkan gaya ortodonti dengan berbagai tipe gerakan menggunakan Finite Element Method. Perkembangan teknologi digital membuat analisis numerik perawatan ortodonti dapat dilakukan dengan melakukan rekonstruksi 3 Dimensi /3D dengan cara memindai gigi kaninus rahang atas dengan CT Scan, sehingga diperoleh 255 citra penampang lintang. Model 3D kemudian diproses menggunakan Finite Element Method untuk memperoleh distribusi tekanan pada jaringan periodontal akibat gerakan tipping, bodily, tork akar, rotasi, dan ekstrusi. Analisis yang digunakan adalah analisis kualitatif dan kuantitatif. Hasil penelitian menunjukkan bahwa tekanan maksimum yang terjadi pada jaringan periodontal akibat berbagai gerakan berkisar antara $3,3 \times 10^{-3} \mathrm{MPa}$ sampai $2,9 \times 10^{-2} \mathrm{MPa}$. Hal ini menunjukkan bahwa gaya yang diberikan pada setiap gerakan menghasilkan tekanan maksimal yang melebihi tekanan pembuluh darah kapiler, yaitu 2 × 10-3 MPa.

Kata kunci: Distribusi tekanan pada jaringan periodontal, tipe gerakan ortodonti, rekonstruksi objek 3-D, Metoda Finite Element

${ }^{*}$ Correspondence author: Elih, Department of Orthodontic Faculty of Dentistry Universitas Padjadjaran
Jl. Sekeloa Selatan No. 1 Bandung, West Java-Indonesia, Tel./Fax: $+6222-2504985 / 2532805$ 


\section{INTRODUCTION}

Orthodontic treatment needs optimum force, which is force that can cause changes in maximal tissue without pain or root resorption and is able to maintain the health of periodontal tissue during tooth movement. ${ }^{1,2}$ Force applied on the teeth is forwarded to the periodontal tissues, the force distributed is important in determining the biological effect. Periodontal tissue response is determined not only by its own force but also by the force on each unit area or pressure. When the force is distributed into the periodontal tissues, different pressures produce different tooth movements. Optimum pressure is the pressure corresponding to the pressure of capillary blood vessels is $15-20 \mathrm{gr} / \mathrm{cm}^{2}$. Patterns and amount of pressure on the periodontal tissues derived from different force, depending on the center of rotation of the teeth. ${ }^{1-4}$

One risk of force application to move the teeth is the occurrence of orthodontic root resorption. Some types of orthodontic movements that can cause root resorption is tipping movement, bodily, and intrusion. Different orthodontic tooth movement can produce different mechanical pressure on some parts of the tooth root. ${ }^{5}$ The factor that initiate biological changes is the pressure that occurs in periodontal tissues, because the level of stress generated by orthodontic force on periodontal tissue is important to be known. ${ }^{6,7}$

Anterior tooth arrangement is an important part of orthodontic treatment. Correction of this section often requires canine withdrawal to the distal anterior teeth followed by setting the arrangement of the crowding anterior teeth and overjet reduction. ${ }^{8}$

Research in the field of orthodontic about materials, equipment, and various forces applied to the tooth and the mouth of the patient is a difficult and expensive procedure, especially the research about the effects of force mechanism against the dental tissue, periodontal tissue and alveolar bone. Difficulties encountered include difficulty in obtaining a homogeneous sample of tooth, difficulty in manufacturing procedures, and the difficulty in using assistive devices for mechanical tests, as well as the difficulty in providing the same treatment on each sample. Research is then do through computer simulation using the Finite Element Method or Finite Element Analysis to avoid the difficulties mentioned above.

Finite Element Analysis (FEA), also called Finite Element Method (FEM), is a combination of mathematics, physics, engineering, and computer discipline. This method has possible applications and extensive benefits as well as its ability to be used to analyze the structure, temperature, and fluid. ${ }^{7}$

Finite Element Method has many advantages such as its able to simplify research by laboratories in which a model can be analyzed under different treatments simulated by a computer. The model can be improved up to reach a maximum prior to testing in the laboratory. Computer simulation is much simpler, able to analyze the design in depth, and able to save time and cost because complicated procedures and specimen manufacture of complex test equipment are unnecessary. ${ }^{9-11}$

Finite Element Method has been widely used to examine the structure of the tooth, biomaterials and restorations, tooth implants and root canals in dentistry. Especially in orthodontic, Finite Element Method has been widely used in several studies, such as on alveolar bone resorption. ${ }^{3,5}$

\section{METHODS}

The study was conducted in the Laboratory of Radiology, Oral and Dental Hospital Faculty of Dentistry Universitas Padjadjaran and in the Laboratory of Lightweight Structures and Aerospace Engineering Faculty of Engineering Institut Technology Bandung. This research was experimental simulation using the Finite Element Method. The sample consisted of a maxillary canine teeth were made of three-dimensional model with Finite Element Method computer program.

Before the analysis was performed using the Finite Element Method, 3D solid model of the maxillary canine tooth and periodontal tissue was reconstructed first, in order to obtain the appropriate model with the desired.

The software used in this study were 3D doctors and CATIA V5 that served to reconstruct a 3D solid model of the maxillary canine tooth and periodontal tissues, as well as the MSC Patran/ Nastran which serves as a software that uses the Finite Element Method to analyze the pressure distribution on the periodontal tissues maxillary 

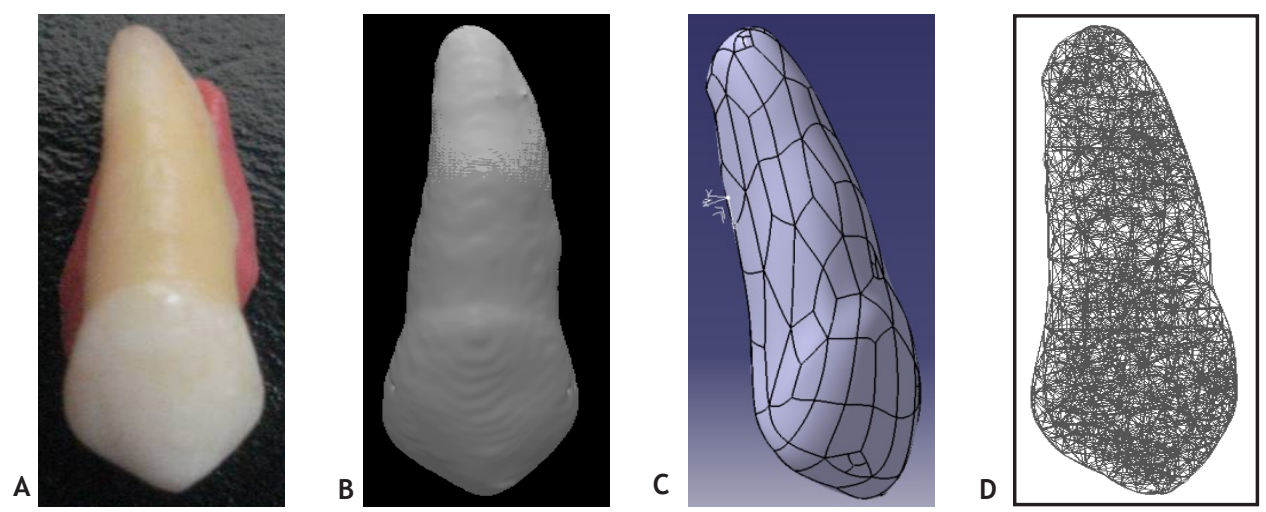

Figure 1. Dental reconstruction and modeling. A. Canine tooth; B. Scanning with CT-Scan; C. Surface reconstruction results; D. Finite Element Method meshing process.

canine tooth due to various types of orthodontic movement of tipping $(0.6 \mathrm{~N})$, bodily $(1.2 \mathrm{~N})$, torque roots $(1 \mathrm{~N})$, rotation $(0.6 \mathrm{~N})$, extrusion $(0.6 \mathrm{~N})$ and intrusion $(0.2 \mathrm{~N})$.

Research procedure consisted of preprocessing stage that includes the manufacture of the model geometry (geometric domain), defines the connectivity elements (meshing), selection of material properties, giving the boundary conditions, and provision expense; solving accept input in the form of figures and generate output in numbers too; and post-processing to display the desired analysis parameters such as voltage, strain and displacement. ${ }^{11}$ In a simulation study using the Finite Element Method performed tooth reconstruction and modeling, as shown in Figure 1.

\section{RESULTS}

The pressure was calculated in units of $\mathrm{MPa}$ and shown with contour color, different colors describe different levels of pressure. Positive values indicate the strain and negative value indicates the pressure.
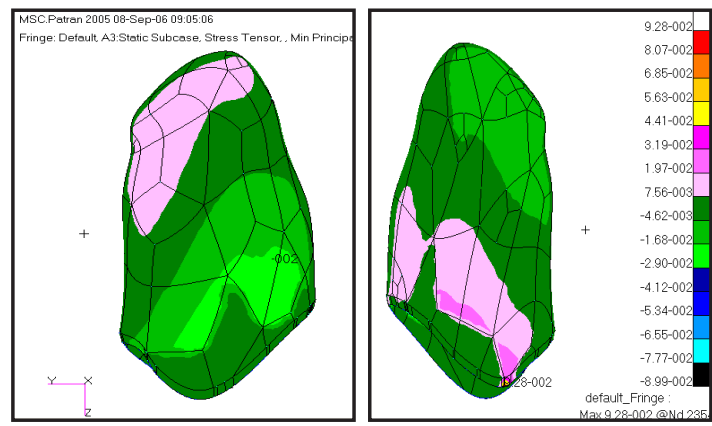

Figure 2. Pressure distribution on periodontal tissues due to tipping movement to mesial.
Distribution of pressure on the periodontal tissues caused by tipping movement is shown in Figure 2. Areas experienced pressure are colored pale green to green, which is $2 / 3$ cervical part of the mesial and $2 / 3$ the apex of the distal part of the maxillary canines, the pressure range between $4.62 \times 10^{-3} \mathrm{MPA}$ to $2.9 \times 10^{-2} \mathrm{MPa}$. Distribution pattern of lavender and purple indicates the strain area of $1 / 3$ the apex of the mesial and $1 / 3$ distal cervical part.

The pressure distribution due to bodily movement is seen in the Figure 3. Areas that are subjected to pressure due to bodily movement are green to dark blue, the value of pressure ranges from $2.58 \times 10^{-3} \mathrm{MPa}$ to $7.93 \times 10^{-3} \mathrm{MPa}$. Distal surface shows the distribution pattern of lavender and dark purple with a positive value indicates that the distal surface undergoes the strained.

Pressure distribution due to torque roots movement is seen in Figure 4. Areas that experienced pressure from roots movement tork are colored light green to light purple, with range value from $5.48 \times 10^{-3} \mathrm{MPa}$ to $1.18 \times 10^{-2} \mathrm{Mpa}$, while the purple-colored pattern to yellow indicates areas experiencing strain of the apical region of
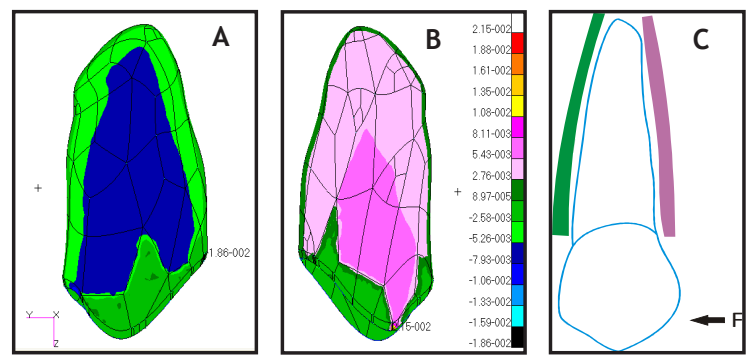

Figure 3. Pressure distribution on periodontal tissues due to bodily movement to mesial caption: (a) Mesial; (b) Distal; (c) tooth motion towards the mesial. 


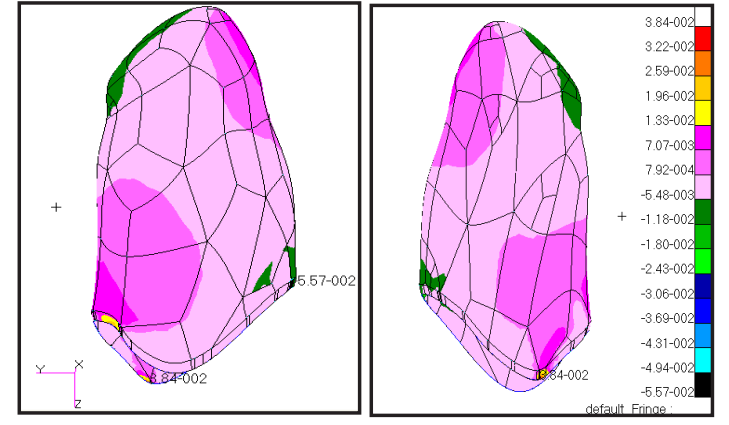

Figure 4. Distribution of pressure on periodontal tissue due torque roots movement: (a) Mesial; (b) Distal.
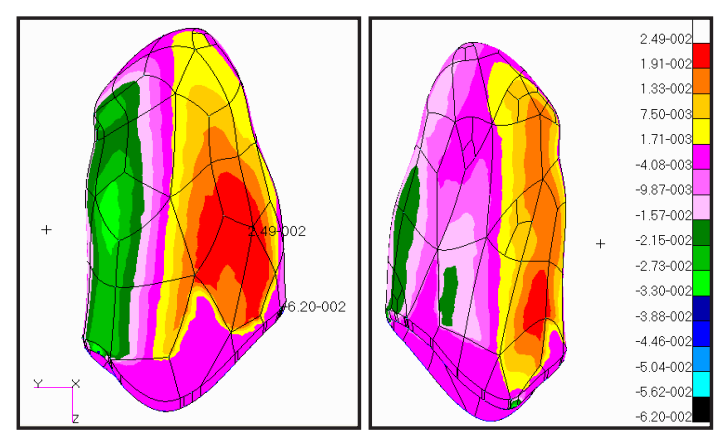

Figure 5. Distribution of pressure in periodontal tissues due to rotation movement: (a) Mesial; (b) Distal.

the buccal and palatal cervical part of the cross section of the mesial and distal.

Pressure distribution due to rotation movement is seen in Figure 5. Areas that experienced pressure are colored purple to light green, with range value from $4.08 \times 10^{-3} \mathrm{MPa}$ to $3.3 \times 10^{-2} \mathrm{MPa}$. Distribution patterns of yellow to red indicates areas experiencing strain.

Distribution pressure due to the extrusion movement is shown in Figure 6. Based on the regular distribution and its negative values the pressure distribution due to the extrusion movement can be determined to range from $3.32 \times 10^{-4} \mathrm{MPa}$ sampai $6.7 \times 10^{-3} \mathrm{MPa}$. Distribution patterns of purple to red indicate areas experiencing strain.

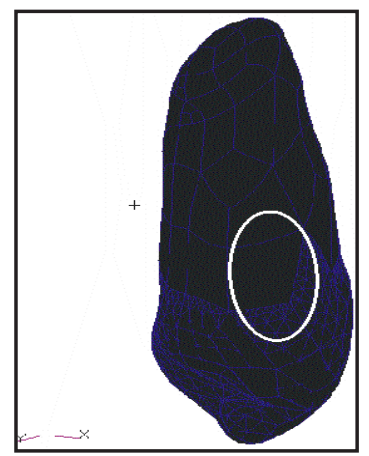

Figure 8. Border connectivity of periodontal tissues nodes.
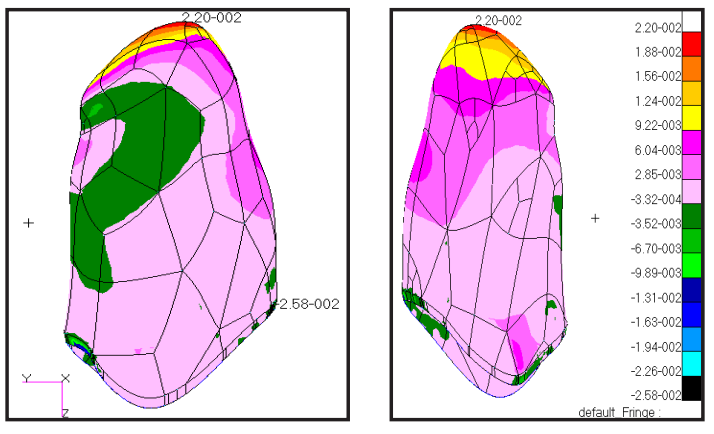

Figure 6. Distribution of pressure on the periodontal tissues due to extrusion movement: (a) Mesial; (b) Distal.
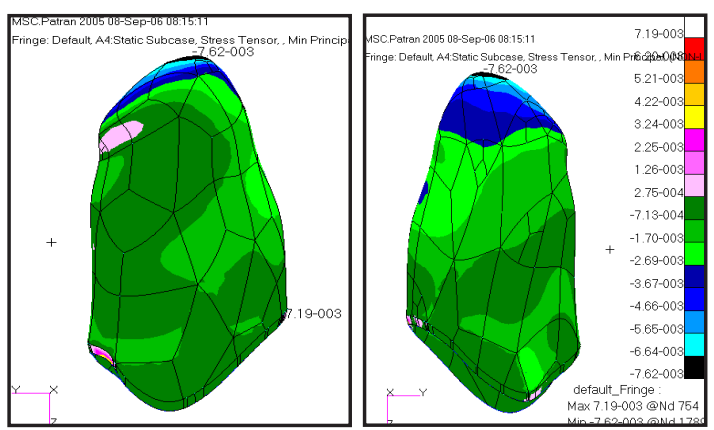

Figure 7. Distribution of pressure in periodontal tissues due to intrusion movement: (a) Mesial; (b) Distal with canine nodes.

Pressure distribution due to the intrusion movement is shown in Figure 7. Distribution of pressure on the periodontal tissues caused by the intrusion movement is marked with the color black to green, with a value of $7.13 \times 10^{-4} \mathrm{MPa}$ to $7.62 \times 10^{-3} \mathrm{MPa}$.

\section{DISCUSSION}

The factor that initiate biological changes on the movement of the teeth is a process of pres-

Table 1. Pressure distribution in canine periodontal tissues

\begin{tabular}{|c|c|c|}
\hline $\begin{array}{c}\text { Type of } \\
\text { movement }\end{array}$ & Pressure (MPa) & $\begin{array}{c}\text { Maximum pressure } \\
\text { area }\end{array}$ \\
\hline Tipping & $4.62 \times 10^{-3}-2.9 \times 10^{-2}$ & $\begin{array}{l}1 / 3 \text { cervical of the } \\
\text { mesial and distal }\end{array}$ \\
\hline Bodily & $2.58 \times 10^{-3}-7,93 \times 10^{-3}$ & $\begin{array}{l}\text { The mesial section of } \\
\text { the root }\end{array}$ \\
\hline Rotation & $5.48 \times 10^{-3}-1.18 \times 10^{-2}$ & $\begin{array}{l}\text { Palatal apex and } \\
\text { buccocervical }\end{array}$ \\
\hline Torque root & $4.08 \times 10^{-3}-3.3 \times 10^{-2}$ & Proximal \\
\hline Extrusion & $3.32 \times 10^{-4}-6,7 \times 10^{-3}$ & Middle $1 / 3$ of the root \\
\hline Intrusion & $7.13 \times 10^{-4}-7,62 \times 10^{-3}$ & Apex \\
\hline
\end{tabular}


sure and strain that occurs in periodontal tissues. Therefore, it is important to know the value of the pressure generated by orthodontic force towards periodontal tissue. In vivo studies are difficult to be done accurately. Therefore, measurements were performed by using Finite Element Method. Maxillary canine was chosen because the canine teeth is single-rooted teeth with the greatest root length and form compared to other single-rooted teeth, besides the maxillary canine retraction is often done on an individual basis.

Canine displacement due to the mesial tipping movement shows the direction of movement of the crown toward the mesial and and the roots toward the distal. A slight rotation of the long axis of the tooth also occurs as a result of the force applied. Pressure distribution due to tipping movement covers $2 / 3$ cervical part of the mesial and $2 / 3$ of the distal part apex. The maximum pressure is shown on $1 / 3$ cervical of the mesial section and $1 / 3$ apical of the distal part as much as $2.9 \mathrm{x}$ $10^{-2} \mathrm{MPa}$ (Fig. 2).

Based on the numerical output from the Finite Element Method, given force of $0.6 \mathrm{~N}$ or 60 grams in tipping movement will produce a maximum pressure of $2.9 \times 10^{-2} \mathrm{MPa}$. It shows that the force which gets in areas experiencing maximum pressure is greater than the optimum pressure expected $\left(2 \times 10^{-3} \mathrm{MPa}\right)$.

Pressure distribution on the bodily movement is lesser and more evenly than the pressure due to tipping movement. Although the bodily movement pressure is evenly distributed, greater pressure is seen in the central part of the roots of $7.93 \times 10^{-}$ ${ }^{3} \mathrm{MPa}$ (Fig. 3). It is relevant to Tanne's research ${ }^{3}$ that says that bodily movement produce maximum pressure in the middle part of the root, although it is contradictive to Proffit's theory ${ }^{1}$ that says that bodily movement creates even pressure. Giving a force of $1.2 \mathrm{~N}$ or 120 grams in bodily movement will produce a maximum pressure of $7.93 \times 10-3$ $\mathrm{MPa}$. This indicates that the force which reaches in areas experiencing maximum pressure is greater than the optimum pressure expected $\left(2 \times 10^{-3} \mathrm{MPa}\right)$.

The canines displacement due to tork roots movement can be seen in Figure 4, the shift toward the palatal apex followed by the tip displacement toward the labial crown. This is in accordance with the opinion of Proffit that the force tork that move the root into the lingual is also followed by a force that drives the crown to the labial. As in patients with Class II malocclusion anchoring is required to maintain the overjet during the roots of the incisives is performed tork to lingual direction by the use of class II elastic.

Based on the pressure distribution, tork of the roots movement produces maximum pressure on the apex of the palatal and cervico labial as much as $1.18 \times 10-2 \mathrm{MPa}$ (Fig. 4). This shows the numerical results of the Finite Element Method, the imposition of $1 \mathrm{~N}$ or 100 grams on the motion of tork produces maximum pressure that is greater than the optimum pressure $\left(2 \times 10^{-3} \mathrm{MPa}\right)$.

Rotational motion produce pressure distribution as shown in Figure 5. The area experiencing pressure is the mesial proximal towards the palatal to the proximal distal area. Maximum pressure is seen in palatal region of $3.3 \times 10^{-2} \mathrm{MPa}$. This shows the numerical results of the Finite Element Method, the imposition of the rotational movement of $1 \mathrm{~N}$ or 100 grams produces the maximum pressure that is greater than the optimum pressure $\left(2 \times 10^{-3} \mathrm{MPa}\right)$.

In this study, extrusion movement produces a depressed area on the periodontal tissues. Theoretically, the extrusion movement does not produce areas that are clinically depressed; however it is difficult to produce extrusion movement without causing a depressed area. It occurs because there is distance between the point of force application with the center of resistance that result in depressed areas on the periodontal tissues. Depressed regions are located on the $2 / 3$ cervical, while the maximum pressure is at the center of of the roots of $6.7 \times 10^{-3} \mathrm{MPa}$ (Fig. 6). Based on numerical results of the Finite Element Method, giving a force of $0.6 \mathrm{~N}$ or 60 grams of the extrusion movement will produce a maximum pressure of $2.9 \times 10^{-2} \mathrm{MPa}$. it shows that the force which reaches in areas experiencing maximum pressure is greater than the optimum pressure.

Intrusion movement produces pressure on all parts of the periodontal tissues, the maximum pressure occurs to the apex region with a value of $7.76 \times 10^{-3} \mathrm{MPa}$ (Fig. 7). Based on numerical results of the Finite Element Method, it shows that giving a force of $0.2 \mathrm{~N}$ or 20 grams on the motion of the intrusion produces a maximum pressure that is greater than the optimum pressure.

Application of force to produce tooth movement in orthodontic often lead to some risks, such 
as root resorption. From these results, the movement of the intrusion produces a maximum pressure in the apex, so if intursion force is to be exerted, especially to patients with teeth that have undergone root resorption, the intrusion force must be applied with caution.

The distribution of pressure jumps occur on some movements such as tipping, bodily, rotation, tork roots, and extrusion. If the location of the maximum pressure seen, there is a fairly drastic change in pressure from low pressure to high pressure. For example, the maximum pressure that occurs in the periodontal tissues are subjected to pressure due to tipping movement is equal to 2.9 $x 10^{-2} \mathrm{MPa}$. According to the writer's observation, the pressure difference is thought to cause local pressure. The reason for it is that the region near the maximum pressure is a border area between the periodontal tissue's nodes and the canine teeth nodes.

Uneven distribution of pressure occurs due to the uneven and complex tooth surface contour creates local stress on certain areas. Besides, it also happens due to the uninvolved alveolar bones in this study.

The weakness of this study is that the alveolar bone is not involved. Periodontal tissue and tissue fluid is formed by elastic fibers. The result of this study is a preliminary description of the pressure. Further study involving the alveolar bone and anisotropic and viscoelastic characteristic of periodontal tissues is necessary. Research using the Finite Element Method can be integrated in clinical trials or animal models to determine the optimal pressure and the relationship between the pressure with tooth movement and bone remodeling.

\section{CONCLUSION}

There is a difference in pressure distribution on the periodontal tissues produced by various types of orthodontic force movements. Giving a force of $0.6 \mathrm{~N}$ on the motion of tipping, $1.2 \mathrm{~N}$ in bodily movement, $1 \mathrm{~N}$ in the root tork, $0.6 \mathrm{~N}$ in rotational motion, the motion extrusions $0.6 \mathrm{~N}$ and $0.2 \mathrm{~N}$ at the intrusion movement produces pressure maximum on the periodontal tissues canines, larger than the capillary pressure value, which is 2 x $10^{-3} \mathrm{MPa}$. Finite Element Method can be used to analyze the pressure distribution on the periodontal tissues caused by orthodontic force in various types of motion.

\section{REFERENCES}

1. Proffit WR, Fields HW, David M, Hendry W. Contemporary orthodontics. $4^{\text {th }}$ ed. St. Louis: CV Mosby Co.; 2007. p. 331-40.

2. Foster TD. A Textbook of orthodontics. $3^{\text {th }}$ ed. Oxford: Blackwell Scientific Publications Ltd.; 1997. p. 169-83.

3. Tanne K. Three dimensional finite element analysis for stress in the periodontal tissue by orthodontic forces. Am J Orthod Dentofac Orthop 1987;92:499-505.

4. Nanda R. Biomechanics and esthetic strategies in clinical orthodontics. St. Louis: Elsevier Saunders; 2005. p. 1-30.

5. David J, Rudolph. A Finite element model of apical force distribution from orthodontic tooth movement. Angle Orthod 2001;71:12731.

6. Andersen KL. Material parameters and stress profiles within the periodontal ligament. Am J Orthod Dentofac Orthoped 1991;99:427-40.

7. Cattaneo PM, Dalstra M. Melsen B. The finite element method: a tool to study orthodontic tooth movement. Angle Orthod 2005;64:17588.

8. Issacson KG, Williams JK. An introduction to fixed appliance. $2^{\text {nd }}$ ed. Bristol: John Wright \& Sons Ltd.; 1990. p. 108-24.

9. Roensch SJ. Finite element analysis. 2010 [cited 2009 Jun 10] Available from:http:// www. finiteelementco./fea.html.

10. Logan DL. A first course in the finite element method. $3^{\text {th }}$ ed. Toronto: Wadsworth Group. Pacific Grove; 2002. p. 1-18

11. Subrata G. Penggunaan finite element analysis dalam penelitian di bidang kedokteran gigi. Kumpulan Makalah Pertemuan IImiah Ilmu Kedokteran Gigi IPROSI I. Bandung: IPROSI; 2007. p. 192-200.

12. Jeon PD, Turiey PK, Moon HB, Ting K. Analysis of stress in the periodontium of the maxillary first molar with a three-dimensional finite element model. Am J Orthod Dentofacial Orthop 1999;115:267-74. 